\title{
SUSTAINABILITY OF THE PENSION SYSTEM OF THE REPUBLIC OF SERBIA
}

\author{
Ana Anufrijev ${ }^{1}$ \\ Goran Dašić
}

DOI: https://doi.org/10.31410/LIMEN.2019.173

\begin{abstract}
The pension system is a very important part of every national economy, not only economically, but also socially and financially. It is known that the first pension in Serbia was paid back in 1833. by Milos Obrenovic, so it would be rightly expected that today, after almost 190 years, that there is a stable public pension system that provides security for today's and future retirees.

It should be noted that in Serbia there is a fear among the population related to private pension funds, known in the literature as the third pillar of pension insurance. Fear is a product of insufficient financial literacy and awareness, on the one hand, but also of the decades-long term to which this insurance applies, on the other.

The problem of the existing public pension system, which is referred to in the literature as ,pay and go", and is also known in practice under the pseudonym "flow boiler", is its unsustainability. Back in the days when a contribution-based insurance system was being developed in Germany, Bismarck envisaged the limit to which the system could operate. This system is suitable for emerging economies and demographics for the benefit of the young population, that is, as long as the number of employees and retirees is 4:1. Difficulties arise when the ratio of employees to retirees is 3:1. The official ratio of employees and pensioners in Serbia is 1.2:1, indicating that a collapse is inevitable.
\end{abstract}

Keywords: Pension system, Employee-pensioner ratio, Demographic structure, PIO contributions.

\section{INTRODUCTION}

Cerbia is like most EU countries faced with numerous problems of the public pension system. A As far as the PAYG system was good while the number of employees who pay contributions was higher than the number of pensioners, so it shows great weaknesses when approaching this magnitude. Nonetheless, it is generally known that the deficiency of the public pension system stems from the fact that the fund's assets are not invested, but are used for current pension payments to pensioners. All EU countries, including Serbia, are awaiting a new reform of the pension system in order to make it more sustainable for future generations. It is also the answer to the question why 14 years after the introduction of the third pillar of Serbia did not try to introduce the second pillar. At this point it is almost certain that the second pillar pension scheme would not bring great benefits.

We like individualized security in exercising the right to pension emphasis should be placed on voluntary pension funds. Those in Serbia recorded a certain growth rate and agreements and membership, but the mass education on this issue is more than necessary. The authors believe that the shares of these funds in Serbia would be greater if the poverty is lower.

\footnotetext{
$1 \quad$ Čačak School of Business, Gradski park 2, 11090 Belgrade, Serbia
}

2 Modern Business School - Terazije 27, 11000 Belgrade, Serbia 


\section{DEMOGRAPHIC PICTURE OF THE REPUBLIC OF SERBIA}

In the last few decades, Serbia has been suffering from demographic processes that are characteristic of almost all European countries. Such a picture is characterized by a process of constant aging of the population, resulting from low fertility rates and an increase in life expectancy. Also, the total population of the Republic of Serbia has been declining due to migration, which has been particularly pronounced in recent years.

According to a statement issued by the Statistical Office of the Republic of Serbia in June 2019, the estimated population in Serbia in the previous year was 6,982,604. Looking at gender, 51.3\% are women, or 3,580,898; while $48.7 \%$ are male, or 3,401,706. The statement points out that the depopulation trend is continuing, which means that the population growth rate is negative compared to the previous year and amounts to $-5.5 \%$. Retrospectively, by year, there were 7,236,519 inhabitants in Serbia in 2011, 7,201,497 inhabitants in 2012, in 2013 the population was 7,166,552, in 2014. there were 7,131,787 inhabitants, in 2015. the population was 7,095,381, in 2016 there were 7,058,322 inhabitants, in 2017 that number was 7,020,858, while in 2018, Serbia had a population of 6,982,604. The graphical representation is given in Chart 1 .

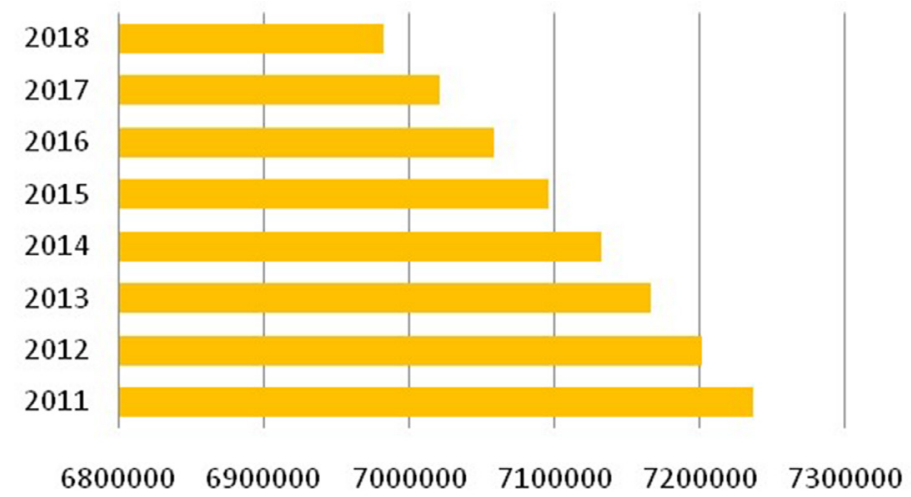

Chart 1. Estimated population in the Republic of Serbia 2011-2018

Source: SORS

According to Kovačević, Gavrilović et al. (Kovačević et al.; 15) the most important feature of the movement of the projected population of the Republic of Serbia over the next forty years is the continuation of the process of depopulation. Their projection is based on five assumptions:

- Realistic, which is the basic projection;

- Low Fertility Projection;

- High Fertility Projection;

- Projection of zero migration balance; and

- Projection of constant migration balance (status quo).

Table 1.1 - Population projections in Serbia

\begin{tabular}{lccccccc} 
Projection variant & $\mathbf{2 0 1 5 .}$ & $\mathbf{2 0 2 0}$ & $\mathbf{2 0 3 0 .}$ & $\mathbf{2 0 4 0 .}$ & $\mathbf{2 0 5 0 .}$ & $\begin{array}{c}\mathbf{2 0 6 0 .} \\
\text { Growth index } \\
\mathbf{( 2 0 1 5 = 1 0 0 )}\end{array}$ \\
\hline Real & 7.095 .381 & 6.858 .597 & 6.338 .252 & 5.906 .790 & 5.688 .346 & 5.569 .805 & 78,5 \\
\hline High Fertility & 7.095 .381 & 6.853 .692 & 6.308 .937 & 5.813 .116 & 5.470 .912 & 5.185 .332 & 73,1 \\
\hline Zero migration balance & 7.095 .381 & 6.865 .943 & 6.393 .056 & 6.023 .178 & 5.881 .760 & 5.880 .467 & 82,9 \\
\hline Constant & 7.095 .381 & 6.914 .805 & 6.544 .343 & 6.125 .551 & 5.783 .179 & 5.461 .742 \\
\hline
\end{tabular}

Source: (2018) Economic, Demographic and Social Effects of Different Scenarios for Normalizing Relations between Belgrade and Pristina, Open Society Foundation, p. 15 
According to the results of the projections, the population of Serbia would increase by 2060. It could range from $3,957,000$ (the status quo) to 5,880,000 (the high fertility variant).

\subsection{Number of employees and pensioners}

The basic indicator of regional economic developments should be to monitor the dynamics of the wage bill by municipalities. This indicator is also suitable for measuring the performance of local authorities in economic development, as well as for measuring the effects of government measures, both through public sector employee remuneration policies and through the ability to attract investment to specific municipalities. In Serbia, big cities such as Belgrade, Novi Sad and Nis differ in the structure of employees from the rest of Serbia. However, this is not the case, and it is similar to all urban capitals and major centers of Europe. However, the main difference from the rest of Serbia stems from the decreasing share of employees in the processing industry and in agriculture, and a larger share of employees in almost all services.

The last two decades for Serbia have been characterized by the number of breakdowns of industrial giants in medium-sized cities. On the other hand, there has been a rapid development of the service sector in Belgrade and Novi Sad, especially in the areas of finance, trade, transport, management, medical and other services. Looking at these two fundamental changes - the breakdown of industry in major cities and the rapid development of Belgrade and Novi Sad, there is a marked dying out of more than half of the municipalities in Serbia, characterized by a relatively small population (below 50,000) with a predominantly agricultural orientation and one or two factories shut down, mainly the textile industry. Many municipalities in Serbia bear the epitome of "slum municipalities" and it is therefore important to know the effects of changes in wage and pension policies on their lives. The following is a table showing the number of pension beneficiaries for the period 1997-2018.

Table 1.2 - Number of pension beneficiaries by type of pension by year

\begin{tabular}{|lcccc|} 
Year & Old-age pension & Disability support pension & Family pension & Total \\
\hline 1997 & 703.794 & 438.401 & 318.111 & $\mathbf{1 . 4 6 0 . 3 0 6}$ \\
1998 & 709.436 & 435.835 & 327.773 & $\mathbf{1 . 4 7 3 . 0 4 4}$ \\
\hline 1999 & 725.197 & 434.820 & 337.958 & $\mathbf{1 . 4 9 7 . 9 7 5}$ \\
2000 & 735.407 & 427.466 & 344.348 & $\mathbf{1 . 5 1 0 . 8 0 1}$ \\
\hline 2001 & 772.440 & 428.040 & 351.511 & $\mathbf{1 . 5 5 1 . 6 9 1}$ \\
\hline 2002 & 756.970 & 413.824 & 336.703 & $\mathbf{1 . 5 1 1 . 4 9 7}$ \\
2003 & 756.893 & 408.245 & 340.434 & $\mathbf{1 . 5 0 5 . 5 7 2}$ \\
\hline 2004 & 763.289 & 398.034 & 344.744 & $\mathbf{1 . 5 0 6 . 0 6 7}$ \\
\hline 2005 & 780.030 & 306.692 & 342.254 & $\mathbf{1 . 5 0 8 . 5 7 6}$ \\
\hline 2006 & 819.076 & 377.936 & 347.036 & $\mathbf{1 . 5 4 4 . 0 4 8}$ \\
\hline 2007 & 851.341 & 368.922 & 349.292 & $\mathbf{1 . 5 6 9 . 3 5 3}$ \\
\hline 2008 & 888.534 & 362.180 & 349.625 & $\mathbf{1 . 5 8 0 . 2 3 9}$ \\
\hline 2009 & 893.332 & 358.115 & 352.220 & $\mathbf{1 . 6 0 3 . 0 6 8}$ \\
\hline 2010 & 919.711 & 352.961 & 353.909 & $\mathbf{1 . 6 2 6 . 5 8 1}$ \\
\hline 2011 & 938.702 & 345.300 & 354.943 & $\mathbf{1 . 6 3 8 . 6 4 5}$ \\
\hline 2012 & 990.565 & 342.741 & 359.834 & $\mathbf{1 . 7 0 3 . 1 4 0}$ \\
\hline 2013 & 1.021 .216 & 334.340 & 367.393 & $\mathbf{1 . 7 2 2 . 6 4 9}$ \\
\hline 2014 & 1.053 .258 & 323.210 & 352.694 & $\mathbf{1 . 7 3 9 . 1 6 2}$ \\
\hline 2015 & 1.064 .380 & 312.357 & 359.205 & $\mathbf{1 . 7 3 5 . 9 4 2}$ \\
\hline 2016 & 1.070 .004 & 303.077 & 354.957 & $\mathbf{1 . 7 2 8 . 1 3 8}$ \\
\hline 2017 & 1.076 .890 & 293.835 & 349.710 & $\mathbf{1 . 7 2 0 . 4 3 5}$ \\
\hline 2018 & 1.085 .144 & 285.192 & 344.316 & $\mathbf{1 . 7 1 5 . 1 5 2}$ \\
\hline
\end{tabular}

Source: SORS 
Number of formally employed in 2018 in Serbia it was 2.3 million and the number of pensioners is 1.2. The relationship is unfavorable due to high unemployment, the informal economy, undeclared work and migration. This means that the system will inevitably have to be transformed.

The conditions for the formation of the second pillar of pension insurance in Serbia have not been sufficiently met. Contribution rates for pension and disability insurance in Serbia are $26 \%$, of which $14 \%$ are at the expense of the employees and $12 \%$ at the expense of the employer. Currently, rates are higher only in Hungary, where they are $30.75 \%$ and in Italy, where they are $33.0 \%$. According to the OECD, in Austria the rates are 9.5\%, in Belgium 16.4\%, in Canada $9.9 \%$, in Denmark 9.8\%, in Finland 25.2\%, in France $25.40 \%$, in $18.7 \%$ in Germany, $19.52 \%$ in Poland, $18 \%$ in Macedonia, and 18\% in Slovakia. (OECD, p.141).

The conclusion of the study «The Challenges of Introducing a Private Pension System in Serbia» is that introducing a second pillar in Serbia is not recommended. Despite the differences, the shared experiences of Hungary and Croatia, which introduced the second pillar as one part of the pension system, show that the real rate of return of pre-retirement pension funds was low, while their operating costs were very high, with decreasing funds in the accounts of future retirees. In addition, the private pension funds market quickly monopolized, that is, their concentration came. Due to the underdevelopment of the financial market and the necessary control of investments to mitigate risk, funds predominantly invested funds in government securities. This means that the savings raised through the funds were not invested through the economy and did not provide an incentive for economic growth, but rather allowed the state to spend more, with potentially negative implications for increasing public debt. Also, the transition cost, implicit or explicit, was high in both cases.

\section{THIRD PILLAR OF RETIREMENT INSURANCE}

The pension systems of all post-socialist countries are based on the first pillar of compulsory state insurance, called the «Generational Solidarity System». Nowadays, this is more and more often an unshackled and archaic model as the working age population approaches the number of retirees. Due to the shortcomings of this system, all countries are considering serious reforms. The fact is that pension systems are in crisis all over the world.

Most economists today consider that Pay as you go pension systems have a misplaced basis and structure. They do not produce or make any real investment, nor specific wealth, but are established as transmission systems that transfer wealth from todayss workers to current retirees. The demographic system elaborated by the authors on the example of Serbia in the first part of the paper is present throughout the European Union, which is following the trend of the «aging nation». Accordingly, the population tends to decrease. In the past, demographic variability has often been underestimated, while economic analyzes have focused on other uncertainty factors that have been used to investigate population age structure (Holzmann, R., \& Palmer, 2006,101).

According to Schwarz, World Bank experts believe that the pension reforms can be grouped into four types of reforms (Schwarz A. 1996):

1. Parametric reforms, which include changes in the parameters of existing pension systems;

2. The system or structural reform, which include the introduction of a new type of pension system, which would fully replace or supplement the existing system only; 
3. Regulatory reforms, which include changes in regulations related to investments of funds, and

4. Administrative reform.

Model "three pillars" proposed by the World Bank has been expanded with two additional pillars: the zero $(0)$ column in order to reduce poverty and IV pillar that includes the wider context of social policy.

Net assets of voluntary pension funds in Serbia at the end of the third quarter of 2019 amounted to 43.5 billion dinars. In the third quarter, net assets increased by $3.36 \%$. The change in the net asset payments affect the net assets of the funds, disbursement of funds and the profit that the funds realized from the investment. In the third quarter of 2019, total payments amounted to the 887,75 million; members withdrew 388,40 million, while income from investments amounted to 930.60 million dinars.

Table 2.1. The net assets in the sector in RSD

\begin{tabular}{|c|c|c|c|c|c|c|c|c|c|c|c|}
\hline 2008 & 2009 & 2010 & 2011 & 2012 & 2013 & 2014 & 2015 & 2016 & 2017 & 2018 & T3 19 \\
\hline 4,6 & 7,2 & 9,9 & 12,5 & 16,0 & 19,7 & 23,6 & 28,9 & 32,8 & 36,2 & 40,2 & 43,5 \\
\hline
\end{tabular}

Source: NBS

At the end of the third quarter of 2019, the stage is 11.199,294 users. They have 272.819 contracts in voluntary pension funds. The share of beneficiaries of pension funds in total employment was $9,4 \%$.

Table 2.2. Number of contracts and the number of users in thousands

\begin{tabular}{|l|c|c|c|c|c|c|c|c|c|c|}
\cline { 2 - 11 } \multicolumn{1}{c|}{} & 2010 & 2011 & 2012 & 2013 & 2014 & 2015 & 2016 & 2017 & 2018 & T3 19 \\
\hline No contracts & 220,4 & 234,4 & 240,4 & 244,5 & 252,1 & 258,1 & 250,5 & 253,9 & 261,7 & 272,8 \\
\hline No Users & 166,8 & 174,9 & 179,8 & 183,5 & 188,0 & 190,5 & 183,6 & 185,4 & 192,3 & 199,3 \\
\hline $\begin{array}{l}\text { \% of active } \\
\text { users in total } \\
\text { users }\end{array}$ & 43,9 & 35,1 & 30,5 & 30,3 & 31,3 & 25,3 & 28,5 & 33,6 & 33,4 & 33,6 \\
\hline
\end{tabular}

Source: NBS

In the first three quarters of the voluntary pension funds were paid 863.66 million. By the end of 2018 year there were paid a total of 847.43 million, out of which 34.3 percent are individual payments, 28.7 percent were based on employers' payments to their employees, while 37 percent relates to payments over the pension plan. The great potential for further growth in the number of pension fund members represent companies with a large number of employees. The savings are possible due to the fact that the payment of pension contributions to voluntary pension funds from the employer exempted from payment of income tax and contributions for compulsory social insurance to the amount of 5,757 dinars per employee per month, and to pay the same amount that the employer is done by administrative measure, the suspension of the payment of the employee's salary, exempt from paying taxes.

Money which have voluntary pension funds, unlike the savings of citizens, is for the most part - even 85.96 percent, in dinars. The remaining part, 14.4 percent, is in euros and dollars.

Most of the money voluntary pension funds are invested in government bonds and those accounted for slightly more than 83 percent of total assets. Then, there is money in shares of 8.55 percent, and the custody accounts and term deposits with banks and to 6.93 percent, and less 
than one percent of the funds were invested in bonds of the European Bank for Reconstruction and Development as well as the investment units of open investment funds.

Yields voluntary pension funds depends on the amount and length of payments into the fund and accumulated funds are increasing as a longer period. This type of pension insurance is gaining ground for most users. The problem is the general poverty of the population, because otherwise these funds were more popular.

\section{CONCLUSION}

Equalizing the number of employees and the number of pensioners creates a challenge for scientific and professional community around the world. Question is how to solve the problems of public pension funds and how will they survive in the future. The situation in Serbia is very dramatic and the Republic Fund for pension insurance will have to undergo additional reforms. Although the age for retirement is moved, for the future operation of the fund it will not be enough. The pension system, what is in effect, was free to work in the 60th and 70th years of the last century. Back then on one pensioner came about six employees. Nowadays, on one pensioner there is one employee, according to experts, so employees should be four times as much to make the system function in general. All this points to the necessity to reform the public pension system in Serbia, which is totally unsustainable in the long term and does not follow global trends. However, the battle with ,time” not only lead Serbia. Pension systems are a problem both in transition and developing countries, and in the developed world economies. As an option for an additional savings of citizens, private pension funds find their place.

\section{REFERENCES}

Holzmann, R., \& Palmer, E. E. (Eds.). (2006). Pension reform: issues and prospects for non-financial defined contribution (NDC) schemes. World Bank Publications.

Kovačević, M., Gavrilović, D., Popović, D., Stevović, M., Sekulić, Lj. i Snančić, K. (2018). Ekonomski, demografski i socijalni efekti različitih scenarija normalizacije odnosa između Beograda i Prištine, Beograd, Fondacija za otvoreno društvo.

Matković, G., Bajec, J., Mijatović, B., Živković, B., \& Stanić, K. (2009). Izazovi uvođenja obaveznog privatnog penzijskog sistema u Srbiji. USAID, Centar za liberalno-demokratske studije, Beograd.

NBS (2019). Sektor dobrovoljnih penzijskih fondova, Izveštaj za treće tromesečje 2019.

OECD (2017), Pensions at a Glance 2017: OECD and G20 Indicators, OECD Publishing, Paris. http://dx.doi.org/10.1787/pension_glance-2017-en, 2017.

Republički zavod za statistiku (2019). Procene stanovništva, 2018.

Schwarz A. (1996). Taking Stock of Pension Reforms Around the World“, HDNSP, World Bank and Asli Demirguc-Kunt, DECRG, World Bank. 